\title{
PENGARUH KOMUNIKASI KERJA, KEPEMIMPINAN DAN PELATIHAN KERJA TERHADAP KEPUASAN KERJA KARYAWAN PADA PT BUMISARI PRIMA MEDAN
}

\author{
Rick Thio Nanda \\ Univesitas Prima Indonesia \\ rickthion@gmail.com \\ Ina Namora \\ Univesitas Prima Indonesia
}

\section{Suggested Citation:}

Budiman, Novelisa P., Saerang, Ivonne S \& Sendow, Greis M. 2016. Pengaruh Kompetensi, Motivasi dan Disiplin Kerja terhadap Kepuasan Kerja (Studi pada PT Hasjrat Abadi Tendean Manado). Jurnal Manajemen, Bisnis dan Akuntansi. Volume 4 Nomor 3, pp. 321-332

\begin{abstract}
:
This research was conducted at PT Bumisari Prima which has long been established and is a leader in the field of starch manufacturing. In this study aims to be able to analyze employee work communication, leadership and employee work training on employee job satisfaction at PT Bumisari Prima. Job satisfaction at this company has decreased due to communication, leadership and job training that has not been optimal. The population is 162 employees of PT Bumisari Prima and the sample is 115 employees of PT Bumisari Prima The research method uses multiple linear regression analysis techniques. The results of the partial hypothesis testing showed that work communication had a positive and significant effect on employee job satisfaction at PT Bumisari Prima (tapioca flour production). Partially shows that Job Communication, Leadership and Job Training have a positive and significant effect on Employee Job Satisfaction at PT Bumisari Prima (tapioca flour production). Simultaneous hypothesis testing shows that Job Communication, Leadership and Job Training have a positive and significant effect on Employee Job Satisfaction at PT Bumisari Prima (tapioca flour production).
\end{abstract}

Keywords: Job Communication, Job Satisfaction, Job Training, Leadership,

\section{Abstrak}

Pada penelitian ini bertujuan untuk menganalisis komunikasi kerja karyawan, kepemimpinan dan pelatihan kerja karyawan terhadap kepuasan kerja karyawan pada PT Bumisari Prima. Kepuasan kerja pada perusahaan ini mengalami penurunan yang disebabkan komunikasi, kepemimpinan dan pelatihan kerja yang belum optimal. Populasi berjumlah 162 karyawan PT Bumisari Prima dan sampel berjumlah 115 karyawan PT Bumisari Prima Metode penelitian mengunakan teknik analisis regresi linear berganda. Hasil penelitian pengujian hipotesis secara parsial menunjukkan bahwa Komunikasi Kerja, berpengaruh positif dan signifikan terhadap Kepuasan Kerja Karyawan pada PT Bumisari Prima. Secara parsial menunjukkan bahwa Komunikasi Kerja, Kepemimpinan dan Pelatihan Kerja berpengaruh positif dan signifikan terhadap Kepuasan Kerja Karyawan pada PT Bumisari Prima. Pengujian hipotesis secara simultan menunjukkan bahwa Komunikasi Kerja, Kepemimpinan dan Pelatihan Kerja berpengaruh positif dan signifikan terhadap Kepuasan Kerja Karyawan pada PT Bumisari Prima.

Kata kunci: Kepemimpunan, Kepuasan Kejra, Kinerja Karyawan. Pelatihan Kerja 


\section{Pendahuluan}

Masih rendahnya kualitas sumber daya manusia dan penanganannya merupakan salah satu masalah yang sering dihadapi oleh bangsa Indonesia ini. Jumlah sumber daya manusia yang begitu besar apabila dapat digunakan secara efektif dan efisien akan sangat bermanfaat untuk menunjang laju pembangunan nasional Negara kita. Menciptakan sumber daya manusia yang berkualitas diperlukan pendidikan yang berkualitas juga penyediaan fasilitas sosial yang memadai, serta lapangan kerja yang memadai. Tantangan sesungguhnya adalah bagaimana kita dapat menciptakan sumber daya manusia yang dapat menghasilkan kinerja yang optimal untuk mencapai tujuan organisasi.

Meningkatkan kualitas sumber daya manusia diharapkan karyawan dapat meningkatkan kinerjanya secara optimal. Kinerja karyawan merupakan suatu tindakan yang dilakukan karyawan dalam melaksanakan pekerjaan yang diberikan perusahaan. Setiap organisasi selalu mengharapkan karyawannya mempunyai prestasi kerja, karena dengan memiliki karyawan yang berprestasi akan memberikan sumbangan yang optimal bagi organisasi dan dapat meningkatkan kinerja perusahaannya. Dengan komptensi kerja karyawan yang baik dan lingkungan kerja yang kondusif dan nyaman dapat membuat karyawan lebih meningkatkan kinerja didalam perusahaan. PT Bumisari Prima merupakan sebuah perusahaan yang bergerak di bidang produksi tepung. Pada penelitian ini hanya menelitian PT Bumisari Prima dalam perusahaan ini. Berdasarkan wawancara terlebih dahulu dan studi dokumentasi yang diperoleh bahwa terjadinya penurunan kepuasan kerja karyawan dalam perusahaan ini yang terlihat dari seringnya karyawan melakukan pelanggaran aturan yang berlaku dan banyaknya karyawan yang lebih memilih keluar dari perusahaan.

Hasil ini sejalan dengan teori menurut Robbins dan Coulter (2013), "Penekanan pada para pengikut dalam efektivitas kepemimpinan mereflesikan kenyataan bahwa pengikutlah yang menerima atau menolak pemimpinnya. Terlepas dari apa yang dilakukan oleh pemimpin, efektivitas kelompok tergantung dari tindakan para pengikutnya." Budiman, dkk. (2016) menyatakan bahwa adanya pengaruh kompetensi terhadap kepuasan kerja karyawan di dalam perusahaan.

Kepemimpinan dalam PT Bumisari Prima masih belum memuaskan para karyawan terbukti dari kurangnya solusi untuk karyawan yang sedang menghadapi masalah dalam pekerjaannya, pembertian tugas maupun hukuman masih belum adil kepada karyawan, penilaiana kinerja yang tidak memuaskan para karyawan.

Menurut Priansa (2015), Aspek ini mengukur kepuasan yang berhubungan dengan komunikasi yang berlangsung dalam pekerjaan. Dengan komunikasi yang berlangsung lancar dalam organisasi, pegawai dapat lebih memahami tugas-tugasnya dan segala sesuatu yang terjadi di dalam organisasi. Khairiyah (2013) menyatakan bahwa adanya pengaruh komunikasi terhadap kepuasan kerja karyawan di dalam perusahaan.

Komunikasi kerja berperan penting di dalam perusahaan. Pada prakteknya dalam perusahaan ini bahwa komunikasi kerja yang terlaksana antara karyawan masih belum harmonis dan jelas sehingga memicu ketidakpahaman karyawan. Hal ini berdampak pada pekerjaan yang terlaksana tidak maksimal karena terdapat pekerjaan yang salah. Ketidakjelasan ini disebabkan lebih banyak mengunakan bahasa yang tidak mudah dimengerti karyawan.

Menurut Fajar, dkk. (2015), "Pelatihan dapat memberikan pengaruh secara signifikan pada produktivitas kerja karyawan dan sikapnya terhadap pekerjaannya. Khairiyah, dkk. (2014) menyatakan bahwa adanya pengaruh pelatihan kerja terhadap kepuasan kerja karyawan di dalam perusahaan. Sistem pelatihan kerja yang masih belum efektif terbukti dari banyaknya karyawan yang kurang termotivasi untuk hadir mengikuti pelatihan kerja yang sedang di adakan. Hal ini diakibatkan jadwal pelatihan yang seringnya bukan hari kerja melainkan hari minggu sehingga banyak karyawan yang malas untuk hadir, seringnya peserta yang ikut tidak sesuai dengan topik pelatihan dengan tanggung jawab dan tugasnya di dalam perusahaan.

Berdasarkan hal yang telah diuraikan sebelumnya, maka peneliti dapat merumuskan tujuan penelitian ini adalah untuk menguji dan menganalisis pengaruh komunikasi kerja, kepemimpinan, dan pelatihan kerja terhadap kepuasan kerja. 


\section{Metode}

Pendekatan dalam penelitian ini adalah pendekatan kuantitatif. Dalam penelitian ini, peneliti menggunakan jenis penelitian deskriptif.Sifat penelitian yang digunakan adalah deskriptif explanatory. Dalam penelitian ini, pengumpulan data terkait permasalahan yang diteliti oleh peneliti dilakukan dengan cara kuesioner, wwancara dan studi dokumentasi. Sumber data penelitian terdiri atas data primer dan sekunder.Peneliti mengambil populasi dalam penelitian ini sebanyak 162 karyawan. Sampel dalam penelitian ini berjumlah 115 orang.

Hasil

Hasil model regresi analisis regresi linear berganda adalah sebagai berikut :

Tabel 1

\begin{tabular}{|c|c|c|c|c|c|c|}
\hline \multicolumn{7}{|c|}{ Hasil Analisis Regresi Linear Berganda } \\
\hline \multicolumn{7}{|c|}{ Coefficients $^{\mathrm{a}}$} \\
\hline \multirow{3}{*}{\multicolumn{2}{|c|}{ Model }} & & & \\
\hline & & \multicolumn{2}{|c|}{ Unstandardized Coefficients } & Coefficients & \multirow[b]{2}{*}{$t$} & \multirow[b]{2}{*}{ Sig. } \\
\hline & & $\mathrm{B}$ & Std. Error & Beta & & \\
\hline \multirow[t]{4}{*}{1} & (Constant) & 4.463 & 1.982 & & 2.252 & .026 \\
\hline & Komunikasi & .144 & .058 & .223 & 2.498 & .014 \\
\hline & Kepemimpinan & .110 & .047 & .210 & 2.373 & .019 \\
\hline & PelatihanKerja & .151 & .064 & .219 & 2.359 & .020 \\
\hline
\end{tabular}

a. Dependent Variable: KepuasanKerja

Sumber: Hasil Penelitian, 2019 (Data diolah)

\section{Kepuasan Kerja = 4,463 + 0,144 Komunikasi+0,110 Kepemimpinan + 0,151 Pelatihan Kerja}

Konstanta sebesar 4,463 menyatakan bahwa jika variabel bebas komunikasi kerja, kepemimpinan dan pelatihan kerja tidak ada atau konstan maka variabel terikat kinerja karyawan PT Bumisari Prima pada sebesar 4,463 satuan. Koefisien regresi variabel bebas komunikasi sebesar 0,344 dan bernilai positif, hal ini menyatakan bahwa apabila setiap kenaikan variabel bebas komunikasi 1 satuan akan meningkatkan variabel terikat kinerja karyawan PT Bumisari Prima sebesar 0,144 satuan dengan anggapan variabel lainnya tetap. Koefisien regresi variabel bebas kepemimpinan sebesar 0,324 dan bernilai positif, hal ini menyatakan bahwa apabila setiap kenaikan variabel bebas kepemimpinan1 satuan akan meningkatkan variabel terikat kinerja karyawan PT Bumisari Prima sebesar 0,110 satuan dengan anggapan variabel lainnya tetap. Koefisien regresi variabel bebas pelatihan kerja sebesar 0,223 dan bernilai positif, hal ini menyatakan bahwa apabila setiap kenaikan variabel bebas pelatihan kerja 1 satuan akan meningkatkan variabel terikat kinerja karyawan PT Bumisari Prima sebesar 0,151 satuan dengan anggapan variabel lainnya tetap.

Berikut hasil pengujian koefisien determinasi yaitu :

Tabel 2

Uji Koefisien Determinasi

Model Summary ${ }^{b}$

\begin{tabular}{lccrr}
\hline \multicolumn{1}{c}{ Model } & R Square & Adjusted R Square & $\begin{array}{c}\text { Std. Error of the } \\
\text { Estimate }\end{array}$ \\
\hline dimension0 1 & $.468^{\text {a }}$ & .219 & .198 & 6.21015 \\
\hline a. Predictors: (Constant), PelatihanKerja, Kepemimpinan, Komunikasi & & \\
\hline b. Dependent Variable: KepuasanKerja & & & \\
\hline Sumber : Hasil Penelitian, 2019(Data diolah)
\end{tabular}


Hasil uji koefisien determinasi sebesar 0,198 hal ini berarti 19,8\% dari variasi variabel terikat kinerja karyawan PT Bumisari Prima yang dapat dijelaskan oleh variasi variabel bebas komunikasi, kepemimpinan dan pelatihan kerja sedangkan sisanya sebesar $80,2 \%$ dijelaskan oleh variabel lain yang tidak diteliti pada penelitian ini, seperti kompensasi finansial, iklim organisasi, penempatan kerja karyawan dan sebagainya.

Pengujian statistik $\mathrm{F}$ pada dasarnya menunjukkan apakah semua variabel bebas yang dimasukkan dalam model mempunyai pengaruh secara simultan terhadap variabel dependen.

Tabel 3

Uji Simultan (Uji F)

\begin{tabular}{llrrrrr}
\hline \multicolumn{7}{c}{ ANOVA $^{\mathrm{b}}$} \\
\hline Model & & Sum of Squares & df & Mean Square & F & \multicolumn{1}{c}{ Sig. } \\
\hline 1 & Regression & 1198.349 & 3 & 399.450 & 10.358 & $.000^{\mathrm{a}}$ \\
& Residual & 4280.816 & 111 & 38.566 & & \\
& Total & 5479.165 & 114 & & & \\
\hline
\end{tabular}

a. Predictors: (Constant), PelatihanKerja, Kepemimpinan, Komunikasi

b. Dependent Variable: KepuasanKerja

Sumber : Hasil Penelitian, 2019 (Data diolah)

Hasil pengujian diperoleh nilai $F_{\text {hitung }}(10,358)>F_{\text {tabel }}(2,69)$ dan nilai probabilitas signifikansi $0,000<0,05$, berarti bahwa Ho ditolak dan Ha diterima yaitu secara simultan Komunikasi Kerja, Kepemimpinan dan Pelatihan Kerja berpengaruh positif dan signifikan terhadap Kepuasan Kerja Karyawan pada PT Bumisari Prima (produksi tepung tapioka). Selanjutnya dilakukan Uji t digunakan untuk mengetahui ada tidaknya hubungan atau pengaruh yang berarti (signifikan) antara variabel independen secara parsial terhadap variabel dependen.

Tabel 4

Uji Parsial (Uji t)

\begin{tabular}{|c|c|c|c|c|c|c|}
\hline \multicolumn{7}{|c|}{ Coefficients $^{a}$} \\
\hline & \multirow{2}{*}{ Model } & \multicolumn{2}{|c|}{ Unstandardized Coefficients } & \multirow{2}{*}{$\begin{array}{c}\text { Standardized } \\
\text { Coefficients }\end{array}$} & \multirow{2}{*}{$\mathbf{t}$} & \multirow{2}{*}{ Sig. } \\
\hline & & B & Std. Error & & & \\
\hline \multirow[t]{4}{*}{1} & (Constant) & 4.463 & 1.982 & & 2.252 & .026 \\
\hline & Komunikasi & .144 & .058 & .223 & 2.498 & .014 \\
\hline & Kepemimpinan & .110 & .047 & .210 & 2.373 & .019 \\
\hline & PelatihanKerja & .151 & .064 & .219 & 2.359 & .020 \\
\hline
\end{tabular}

a. Dependent Variable: KepuasanKerja

Sumber: Hasil Penelitian, 2019 (Data diolah)

Hasil perhitungan pengujian hipotesis secara parsial diperoleh nilai $t_{\text {hitung }}>t_{\text {tabel }}$ atau 2,498 $>1,982$ dan signifikan yang diperoleh $0,014<0,05$, berarti bahwa Ho ditolak dan Ha diterima yaitu secara parsial Komunikasi Kerja berpengaruh positif dan signifikan terhadap Kepuasan Kerja Karyawan pada PT Bumisari Prima (produksi tepung tapioka). Hasil perhitungan pengujian hipotesis secara parsial diperoleh nilai thitung $>t_{\text {tabel }}$ atau 2,373 $>$ 1,982 dan signifikan yang diperoleh $0,019<0,05$, berarti bahwa Ho ditolak dan Ha diterima yaitu secara parsial Kepemimpinan berpengaruh positif dan signifikan terhadap Kepuasan Kerja Karyawan pada PT Bumisari Prima (produksi tepung tapioka). Hasil perhitungan pengujian hipotesis secara parsial diperoleh nilai $t_{\text {hitung }}>t_{\text {tabel }}$ atau 2,359 > 1,982 dan signifikan yang diperoleh $0,020<0,05$, berarti bahwa Ho ditolak dan Ha diterima yaitu secara parsial Pelatihan Kerja berpengaruh positif dan signifikan terhadap Kepuasan Kerja Karyawan pada PT Bumisari Prima (produksi tepung tapioka). 


\section{Pembahasan}

\section{Pengaruh Komunikasi terhadap Kepuasan Kerja Karyawan}

Hasil perhitungan pengujian hipotesis secara parsial diperoleh nilai $t_{\text {nitung }}>t_{\text {tabel }}$ atau 2,498 $>1,982$ dan signifikan yang diperoleh $0,014<0,05$, berarti secara parsial Komunikasi Kerja berpengaruh positif dan signifikan terhadap Kepuasan Kerja Karyawan pada PT Bumisari Prima (produksi tepung tapioka). Hasil ini sejalan dengan teori menurut Priansa (2015), Aspek ini mengukur kepuasan yang berhubungan dengan komunikasi yang berlangsung dalam pekerjaan. Dengan komunikasi yang berlangsung lancar dalam organisasi, pegawai dapat lebih memahami tugas-tugasnya dan segala sesuatu yang terjadi di dalam organisasi.

Komunikasi merupakan aktifitas manusia yang sangat penting baik dalam kehidupan berorganisasi maupun dalam kehidupan sosial. Dlam keseharian di sadari atau tidak komunikasi sudah menjadi bagian dari kehidupan manusia itu sendiri. Untuk menjalin hubungan yang harmonis diperlukan rasa kemanusiaan yang akarb dan saling pengertian sesame anggota masyarakat. Hal tu bias terjadi karena adanya komunikasi yang dilakukakan oleh anggota masyarakat. Dengan komunikasi kita dapat meminimalisir konflik yang ada dalam kehidupan sehari-hari, baik itu konflik antar individu, antar kelompok maupun konflik antar organisasi.

Komunikasi kerja berperan penting di dalam perusahaan. Pada prakteknya dalam perusahaan ini bahwa komunikasi kerja yang terlaksana antara karyawan masih belum harmonis dan jelas sehingga memicu ketidakpahaman karyawan. Hal ini berdampak pada pekerjaan yang terlaksana tidak maksimal karena terdapat pekerjaan yang salah. Ketidakjelasan ini disebabkan lebih banyak mengunakan bahasa yang tidak mudah dimengerti karyawan.

\section{Pengaruh Kepemimpinan terhadap Kepuasan Kerja Karyawan}

Hasil perhitungan pengujian hipotesis secara parsial diperoleh nilai $t_{\text {hitung }}>t_{\text {tabel }}$ atau 2,373 $>$ 1,982 dan signifikan yang diperoleh $0,019<0,05$, berarti secara parsial Kepemimpinan berpengaruh positif dan signifikan terhadap Kepuasan Kerja Karyawan pada PT Bumisari Prima (produksi tepung tapioka). Hasil ini sejalan dengan teori menurut Robbins dan Coulter (2013), "Penekanan pada para pengikut dalam efektivitas kepemimpinan mereflesikan kenyataan bahwa pengikutlah yang menerima atau menolak pemimpinnya. Terlepas dari apa yang dilakukan oleh pemimpin, efektivitas kelompok tergantung dari tindakan para pengikutnya.

Kepemimpinan yang efektif sangat dipengaruhi oleh kepribadian pemimpin. Setiap pemimpin perlu memiliki aspek-aspek kepribadian yang dapat menunjang usahanya dalam mewujudkan hubungan manusia yang efektif dengan anggota organisasinya. Kesuksesan atau kegagalan suatu organisasi ditentukan oleh banyak hal, yang salah satunya adalah kepemimpinan yang berjalan dalam organisasi tersebut. Pemimpin yang sukses adalah apabila pemimpin tersebut mampu menjadi pencipta dan pendorong bagi bawahannya dengan menciptakan suasana dan budaya kerja yang dapat memacu pertumbuhan dan perkembangan kinerja karyawannya. Pemimpin tersebut memiliki kemampuan untuk memberikan pengaruh positif bagi karyawannya untuk melakukan pekerjaan sesuai dengan yang diarahkan dalam rangka mencapai tujuan yang ditetapkan.

Kepemimpinan dalam PT Bumisari Prima masih belum memuaskan para karyawan terbukti dari kurangnya solusi untuk karyawan yang sedang menghadapi masalah dalam pekerjaannya, pembertian tugas maupun hukuman masih belum adil kepada karyawan, penilaiana kinerja yang tidak memuaskan para karyawan.

\section{Pengaruh Pelatihan Kerja terhadap Kepuasan Kerja Karyawan}

Hasil perhitungan pengujian hipotesis secara parsial diperoleh nilai $t_{\text {hitung }}>t_{\text {tabel }}$ atau 2,359 $>1,982$ dan signifikan yang diperoleh $0,020<0,05$, berarti bahwa Ho ditolak dan Ha diterima yaitu secara parsial Pelatihan Kerja berpengaruh positif dan signifikan terhadap Kepuasan Kerja Karyawan pada PT Bumisari Prima (produksi tepung tapioka). Hasil ini sejalan dengan teori menurut Fajar, dkk. (2015), "Pelatihan dapat memberikan pengaruh secara signifikan pada produktivitas kerja karyawan dan sikapnya terhadap pekerjaannya. 
Pelatihan merupakan kewajiban perusahaan dan semua pihak yang terkait dalam pengembangan dan perencanaan usaha. Hal ini dikarenakan dengan diadakannya pelatihan, maka perusahaan melakukan investasi jangka panjang terhadap pengembangan nilai yang dimiliki perusahaan. Melalui adanya pelatihan, perusahaan dapat mengembangkan serta menambah pengetahuan dan keterampilan karyawan sehingga dapat semakin mengefisiensikan dan mengefektifkan kinerja karyawan. Penilaian atas pelaksanaan pekerjaan yang dilaksanakan karyawan atau sering disebut juga sebagai penilaian kinerja atau penilaian prestasi juga mutlak dilakukan untuk melihat sampai sejauh mana keberhasilan pelatihan dan kepuasan kerja karyawan tersebut.

Sistem pelatihan kerja yang masih belum efektif terbukti dari banyaknya karyawan yang kurang termotivasi untuk hadir mengikuti pelatihan kerja yang sedang di adakan. Hal ini diakibatkan jadwal pelatihan yang seringnya bukan hari kerja melainkan hari minggu sehingga banyak karyawan yang malas untuk hadir, seringnya peserta yang ikut tidak sesuai dengan topik pelatihan dengan tanggung jawab dan tugasnya di dalam perusahaan.

\section{Kesimpulan}

Berdasarkan hasil dan pembahasan bahwa dapat disimpulkan bahwa baik secara parsial maupun simultan Komunikasi Kerja, Kepemimpinan, dan Pelatihan Kerja berpengaruh positif dan signifikan terhadap Kepuasan Kerja karyawan. Berdasarkan hasil penelitian ini adapun saran yang diberikan dalam rangka meningkatkan kepuasan kerja karyawan PT Bumisari Prima adalah dengan meningkatkan komunikasi kerja di antara karyawan dengan cara memperbanyak peralatan dan perlengkapan komunikasi yang bertujuan mempermudahkan karyawan dalam melaksanakan tugasnya, memperbaiki cara kepemimpinan yang lebih dapat memotivasi semangat karyawan agar lebih optimal dan maksimal dalam melaksanakan tugasnya, serta memperbaiki sistem pelatihan kerja dengan mengatur bahan pelatihan yang sesuai dengan tugas peserta latihan.

\section{Daftar Pustaka}

Al Fajar, Siti, Heru, Tri. 2015. Manajemen Sumberdaya Manusia. Yogyakarta: Unit Penerbit Dan Percetakan STIM. YPKN

Budiman, Novelisa P., Saerang, Ivonne S \& Sendow, Greis M. 2016. Pengaruh Kompetensi, Motivasi dan Disiplin Kerja terhadap Kepuasan Kerja (Studi pada PT Hasjrat Abadi Tendean Manado). Jurnal Manajemen, Bisnis dan Akuntansi. Volume 4 Nomor 3, pp. 321-332

Khairiyah, Khairiyah dan Annisa, Nur Syaima. 2013. Pengaruh Komunikasi, Gaya Kepemimpinan dan Motivasi Kerja terhadap Kepuasan Kerja pada PT Nutricia Indonesia Sejahtera. Jurnal Elektronik. Volume 5. Pp 323330

Priansa, Juni Donni. 2015. Perencanaan dan Pengembangan Sumber Daya Manusia. Bandung : Alfabeta.

Robbins, Stephen P. 2013. Manajemen. Jakarta : Raja Grafindo Persada. 